[Regular Paper]

\title{
Methanol Biosynthesis from Methane Using Methylosinus trichosporium OB3b Grown in Medium Containing High Copper Concentration
}

\author{
Akimitsu MIYAJI \\ School of Materials and Chemical Technology, Tokyo Institute of Technology, \\ 4259-G1-14, Nagatsuta-cho, Midori-ku, Yokohama 226-8502, JAPAN
}

(Received September 14, 2020)

\begin{abstract}
Methanol production from methane in a batch reactor using whole cells of Methylosinus trichosporium OB3b grown in medium containing $50 \mu \mathrm{mol} \mathrm{L} \mathrm{L}^{-1}$ copper was examined. Methanol productivity of the biocatalyst was $9.56 \mathrm{mmol}$ g-dry cell ${ }^{-1} \mathrm{~h}^{-1}$, about 3 -fold higher than that of the bacteria grown in medium containing $1.25 \mu \mathrm{mol}$ $\mathrm{L}^{-1}$ copper, indicating that methanol productivity of the methane bioconversion is improved by higher copper concentration in the growth medium. Methanol production almost ceased after 60-h reaction due to product inhibition. Therefore, repeated batch reaction was performed, in which the bacterial cells were collected after 24-h reaction and re-used in the next cycle. In the fourth cycle, $83 \%$ of the methanol productivity was retained. About $856 \mathrm{mmol} \mathrm{g-dry} \mathrm{cell}^{-1}$ of methanol was obtained after 4 cycles, which was 3.7 -fold higher than the methanol obtained in a single batch reaction for $96 \mathrm{~h}$.
\end{abstract}

\section{Keywords}

Methane conversion, Methanol production, Biocatalyst, High copper concentration

\section{Introduction}

Methane is an abundant energy and carbon resource found in natural and shale gas deposits, and biogas waste produced by biological systems. The major use of methane is presently as a fuel, but considerable quantities are flared into the atmosphere despite the extensive potential as a carbon source ${ }^{1) \sim 3)}$. However, recent concerns about the environmental impacts and depletion of fuel resources have accelerated the requirement for the sustainable development goals (SDGs). Accordingly, alternative, more energy-efficient and highly selective processes of methane conversion to liquid, storable fuels and useful chemicals are desirable to establish more efficient utilization of methane resources. Methanol production is one important use of methane. Presently, methanol is produced from methane via syngas, a mixture of carbon monoxide and hydrogen ${ }^{1 \sim 3)}$. However, this methanol production process is not optimal as sustainable methanol production because of the high temperature and pressure conditions, and large $\mathrm{CO}_{2}$ emissions as a by-product ${ }^{1), 3)}$. Development of an alternative direct conversion process under mild conditions other than such indirect, high energy requirement processes is strongly desired ${ }^{3) \sim 5 \text { ). }}$.

DOI: doi.org/10.1627/jpi.64.29

* E-mail: miyaji.a.aa@m.titech.ac.jp
One of the strategies for a sustainable methanol production from methane is the use of methane-utilizing bacteria (methanotrophs) as a biocatalyst ${ }^{3), 6)}$. The bacteria utilize methane as the carbon and energy sources for growth at ambient temperature and pressure ${ }^{7)}$. Methanol is produced as an intermediate metabolite by methane monooxygenases (MMOs) enzymes by the bacterial metabolism. Such biological methane conversion is energy-efficient with high selectivity for methanol. Accordingly, industrial synthesis of methanol from methane using a methanotroph as a biocatalyst has been studied. Methylosinus trichosporium OB3b, which expresses particulate methane monooxygenase (pMMO) in the intracytoplasmic membrane of the bacterial cells, has been widely studied for this application $^{3), 6)}$. Studies of methane conversion in a batch reactor are summarized in Table $\mathbf{1}^{8) \sim 14)}$.

Efficient bacterial production of methanol from methane, requires two modifications to the biochemical reactions, inhibition of methanol dehydrogenase (MDH) and supply of electron donors, as shown in Fig. 1. $\mathrm{MDH}$ rapidly oxidizes the methanol produced by $\mathrm{pMMO}$ from methane. Cyclopropanol, $\mathrm{NaCl}$, and ETDA have been used as inhibitors (Table 1) ${ }^{10) \sim 12), 15), 16)}$. Supply of electron donors is required because the physiological electron donor, nicotinamide adenine dinucleotide (NADH), is consumed during the oxidation of methane to methanol by pMMO, while metabolic synthesis is 
Table 1 Previous Reports of Methanol Biosynthesis from Methane with M. trichosporium OB3b in a Batch Reactor

\begin{tabular}{|c|c|c|c|c|c|c|c|c|}
\hline \multirow[b]{2}{*}{ Research group } & \multirow[b]{2}{*}{ Year } & \multirow{2}{*}{$\begin{array}{c}\text { Copper } \\
\text { concentration in } \\
\text { the growth } \\
\text { medium } \\
{\left[\mu \mathrm{mol} \mathrm{L}^{-1}\right]}\end{array}$} & \multirow[b]{2}{*}{$\begin{array}{c}\text { Temp. } \\
{\left[{ }^{\circ} \mathrm{C}\right]}\end{array}$} & \multicolumn{2}{|c|}{ Reaction conditions } & \multirow{2}{*}{$\begin{array}{l}\text { Maximum methanol } \\
\text { concentration }{ }^{\mathrm{a})} \\
{\left[\mathrm{mmol} \mathrm{L}^{-1}\right.} \\
\left.\left(\mathrm{mmol} \text { g-dry cell }{ }^{-1}\right)\right]\end{array}$} & \multirow{2}{*}{$\begin{array}{c}\text { Methanol } \\
\text { productivity } \\
{\left[\text { mmol g-dry cell }{ }^{-1} \mathrm{~h}^{-1}\right]}\end{array}$} & \multirow[b]{2}{*}{ Ref. } \\
\hline & & & & $\begin{array}{c}\text { Cell density } \\
{\left[\text { g-dry cell }{ }^{-1} \mathrm{~L}^{-1} \text { ] }\right.}\end{array}$ & $\begin{array}{c}\text { MDH } \\
\text { inhibitor }\end{array}$ & & & \\
\hline Takeguchi et al. & 1997 & 1.25 & 25 & 0.035 & $\begin{array}{l}\text { Phosphate, } \\
\text { Cyclopropanol }\end{array}$ & $5.3(152)$ & 1.9 & 8 \\
\hline Furuto et al. & 1999 & 1.25 & 25 & 0.035 & $\begin{array}{l}\text { Phosphate, } \\
\text { Cyclopropanol }\end{array}$ & $6.0(160)$ & 2.9 & 9 \\
\hline Lee $e t a l$. & 2004 & 5 & 25 & 0.6 & Phosphate, $\mathrm{NaCl}$ & $7.7(13)$ & 4.3 & 10 \\
\hline Kim et al. & 2010 & 5 & 25 & 0.6 & $\begin{array}{l}\text { Phosphate, } \mathrm{NaCl} \text {, } \\
\text { EDTA }\end{array}$ & $13.2(22)$ & 3.8 & 11 \\
\hline Duan et al. & 2011 & 1 & 30 & 17.3 & Phosphate, $\mathrm{MgCl}_{2}$ & $35.3(2)$ & 0.077 & 12 \\
\hline Pen et al. & 2014 & 5 & 30 & 1.27 & $\begin{array}{l}\text { Phosphate, } \mathrm{NaCl} \text {, } \\
\text { EDTA }\end{array}$ & $9.1(7.1)$ & 8.4 & 13 \\
\hline Hwang et al. & 2015 & 5 & 30 & 0.5 & Phosphate & $12.3(25)$ & 6.3 & 14 \\
\hline
\end{tabular}

a) Methanol concentrations are shown as the amount of methanol per volume of reaction mixture and the amount per dry weight of biocatalyst. b) Determined from the reaction period where the production rate of methanol was constant.

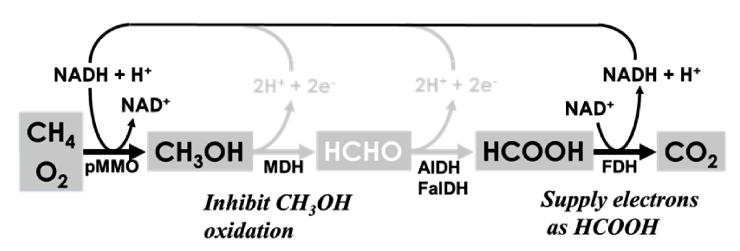

Fig. 1 Strategy for Methanol Production from Methane Based on the Methane Metabolism of Bacterial Cells of Methanotroph

suppressed by the inhibition of MDH. Therefore, formate is supplied to the reaction mixture to regenerate NADH in the bacterial cells $\left(\right.$ Fig. 1) ${ }^{16)}$. Formate is oxidized to carbon dioxide, coupled with NADH regeneration by formate dehydrogenase.

Methanol productivity of biocatalytic methane conversion in the batch reactor has reached $8.4 \mathrm{mmol}$ g-dry cell $\mathrm{h}^{-1}$ by optimizing the reaction conditions and the reactor design (Table 1). However, methanol productivity should be increased to be over $30 \mathrm{mmol} \mathrm{g}^{-1}$ dry cell $\mathrm{h}^{-13)}$ for biocatalytic methanol production on the industrial scale. One of the strategies for increasing productivity is the use of methanotrophic bacterial cells expressing a high quantity and quality of pMMO. The quantity of pMMO expressed in the cells of M. trichosporium $\mathrm{OB} 3 \mathrm{~b}$ depends on the copper concentration in the culture medium; with higher amount of pMMO expressed in the bacterial cells with higher copper concentration in the medium ${ }^{14), 17)}$. High expression was achieved by culturing the bacteria in medium with copper concentrations up to $\left.\left.50 \mu \mathrm{mol} \mathrm{L}^{-1} 14\right), 17\right)$. Therefore, M. trichosporium OB3b cultured with $50 \mu \mathrm{mol} \mathrm{L}{ }^{-1}$ copper is expected to show superior methanol productivity in the bioconversion of methane. However, growth of bacteria in the presence of high copper concentrations is difficult due to the toxicity of copper. Recently, we established a way to overcome this difficulty by cultur- ing the bacteria with cyanocobalamin ${ }^{17)}$.

The present study examined methanol production using whole cells $M$. trichosporium OB3b cells grown under high copper concentration to assess the biocatalyst effectiveness for energy-efficient methanol synthesis from methane. M. trichosporium OB3b was cultured in a medium containing $50 \mu \mathrm{mol} \mathrm{L} \mathrm{L}^{-1}$ copper with cyanocobalamin and applied the resting cells to methanol production from methane in a batch reactor. For comparison, methanol production was also performed using bacterial cells grown in culture mediums containing $1.25 \mu \mathrm{mol} \mathrm{L}{ }^{-1}$ and $10 \mu \mathrm{mol} \mathrm{L}^{-1}$ copper. We expected that the bacteria grown in high copper concentration would achieve higher methanol productivity through methane bioconversion.

\section{Materials and Methods}

\section{1. Batch Culture of $M$. trichosporium OB3b}

M. trichosporium OB3b was kindly donated by Professor T. Kamachi, Tokyo Institute of Technology, Tokyo, Japan. The bacteria were cultured using a method previously reported ${ }^{18)}$ with some modifications. The bacteria were stored at $-80{ }^{\circ} \mathrm{C}$ in glycerol and transferred into $25 \mathrm{~mL}$ of nitrate mineral salt (NMS) medium containing $50 \mu \mathrm{mol} \mathrm{L}{ }^{-1} \mathrm{CuSO}_{4}$ and $100 \mu \mathrm{mol}$ $\mathrm{L}^{-1}$ cyanocobalamin (Sigma-Aldrich, St. Louis, USA) in a $100 \mathrm{~mL}-$ Erlenmeyer flask with baffles. Note that not all $\mathrm{CuSO}_{4}$ added may be dissolved in the medium, although $\mathrm{CuSO}_{4}$ was added through a $0.45 \mu \mathrm{m}$ sterile filter (Millex ${ }^{\circledR}$ Syringe Filter Unit, Merck Millipore, Massachusetts, USA) to the medium after autoclave sterilization to avoid precipitation of copper and absence of copper precipitation was visually confirmed.

The flask was sealed with a silicone cap with a gas inlet tube fitted with a $0.45 \mu \mathrm{m}$ sterile filter $\left(\mathrm{Millex}^{\circledR}\right.$ Vent Filter Unit, Merck Millipore, Massachusetts, 
USA). The pressure of the gas phase in the flask was reduced to $0.02 \mathrm{MPa}$ (gauge pressure) using a hand pump. Then, methane gas was introduced as a carbon source from a balloon. The bacteria were cultured for 2 days in a rotary shaking incubator at $30{ }^{\circ} \mathrm{C}, 225 \mathrm{rpm}$, during which the bacterial growth entered the logarithmic growth phase. The pre-cultured bacteria were transferred to $1 \mathrm{~L}$ of NMS medium containing $50 \mu \mathrm{mol}$ $\mathrm{L}^{-1} \mathrm{CuSO}_{4}$ in a $5 \mathrm{~L}$-Erlenmeyer flask. Methane gas was introduced into the gas phase as described above. Then, the bacteria were cultured for 3 days in the rotary shaking incubator at $30{ }^{\circ} \mathrm{C}, 150 \mathrm{rpm}$, during which the bacterial growth continued in the logarithmic growth phase. Bacterial growth was detected by measuring the turbidity of the culture spectrophotometrically at $660 \mathrm{~nm}$.

The cultured cells were harvested by centrifugation $\left(23,500 \times g, 15 \mathrm{~min}, 4{ }^{\circ} \mathrm{C}\right)$ of the culture medium; the collected bacterial cells were suspended in $12.9 \mathrm{mmol}$ $\mathrm{L}^{-1}$ phosphate buffer, $\mathrm{pH}$ 7.0. The bacterial cells were frozen in liquid nitrogen and stored at $-80{ }^{\circ} \mathrm{C}$.

\section{2. Methane Conversion to Methanol by Whole Cells of M. trichosporium OB3b}

Methane conversion to methanol by whole cells of $M$. trichosporium OB3b was carried out in a Schlenk-type glass tube $(50 \mathrm{~mL}$, Kanto Chemical Co., Inc., Tokyo, Japan) containing $17.5 \mathrm{~mL}$ of the reaction mixture. As the reaction mixture, $12.9 \mathrm{mmol} \mathrm{L}^{-1}$ phosphate buffer, $\mathrm{pH} 7.0$, containing $0.035 \mathrm{~g}$-dry cell $\mathrm{L}^{-1}$ of the bacterial cells, $14.3 \mathrm{mmol} \mathrm{L}^{-1}$ of sodium formate, and $67 \mathrm{nmol}$ $\mathrm{L}^{-1}$ of cyclopropanol was used ${ }^{8)}$. Sodium formate was added as the electron donor and cyclopropanol as the inhibitor for methanol dehydrogenase (Fig. 1). The pressure of the gas phase in the tube was reduced to $0.02 \mathrm{MPa}$ (gauge pressure) using a hand pump. The reaction was initiated by introducing methane gas and performed in a water bath at $25^{\circ} \mathrm{C}$. Bacterial cells were collected from the reaction mixture for repeated batch reaction by using the centrifuge filter, Amicon Ultra-15 (Merck KGaA, Darmstadt, Germany).

The products in the reaction mixture were analyzed by gas chromatography. The amount of methanol produced was determined using a TC-WAX column $(30 \mathrm{~m}$ $\times 0.25 \mathrm{~mm}$ i.d., $0.25 \mu \mathrm{m}$ film thickness, GL Sciences Inc., Tokyo, Japan) and a flame ionization detector. The temperature program was as follows: $40{ }^{\circ} \mathrm{C}$ for 5 $\min$, then $5{ }^{\circ} \mathrm{C} / \mathrm{min}$ to $200{ }^{\circ} \mathrm{C}$. The amount of methanol in the reaction mixture was calculated from the area of all peaks due to methanol, together with standard curves generated using reference methanol.

\section{3. pMMO Activity Assay of the Membrane Fraction}

pMMO activity of the bacterial cells of $M$. trichosporium $\mathrm{OB} 3 \mathrm{~b}$ was measured with the membrane fraction containing pMMO prepared in a chamber kept at $4{ }^{\circ} \mathrm{C}$



acid (MOPS) (pH 7.0) buffer containing $0.5 \mathrm{~mol} \mathrm{~L}^{-1}$ $\mathrm{KCl}$ buffer was cooled to $4{ }^{\circ} \mathrm{C}$ and purged with nitrogen gas to remove dissolved oxygen. Approximately $30 \mathrm{~g}$ $\left(0.5 \mathrm{~g}\right.$-wet cell $\left.\mathrm{mL}^{-1}\right)$ of the frozen cell suspension of $M$. trichosporium $\mathrm{OB} 3 \mathrm{~b}$ stored at $-80{ }^{\circ} \mathrm{C}$ was thawed and centrifuged to separate the bacterial cells $(23,500 \times g$, $20 \mathrm{~min}, 4{ }^{\circ} \mathrm{C}$ ). Approximately $15 \mathrm{~g}$-wet weight cell of the collected bacterial cells were suspended in $30 \mathrm{~mL}$ of $25 \mathrm{mmol} \mathrm{L}^{-1}$ MOPS (pH 7.0) buffer solution. This cell suspension was transferred to a $100 \mathrm{~mL}$ beaker, and DNase I, $\mathrm{MgCl}_{2} 6 \mathrm{H}_{2} \mathrm{O}, \mathrm{CuSO}_{4} 5 \mathrm{H}_{2} \mathrm{O}$, and benzamidine were added to final concentrations of $10,4,0.3$, and $1 \mathrm{mmol} \mathrm{L}^{-1}$, respectively. The suspension of bacterial cells was disrupted with an ultrasonicator (Tomy Seiko Co., Ltd., Tokyo, Japan) on ice under a nitrogen atmosphere. The sonicated suspension was centrifuged $\left(23,500 \times g, 20 \mathrm{~min}, 4{ }^{\circ} \mathrm{C}\right)$ to remove unbroken cells. The supernatant was then centrifuged $(170,000 \times g$, 90 min, $4{ }^{\circ} \mathrm{C}$ ) (CS100GXII, Hitachi Koki Co., Ltd.), and the membrane fraction containing pMMO was pelleted, then suspended in $25 \mathrm{mmol} \mathrm{L}{ }^{-1}$ MOPS buffer, $\mathrm{pH}$ 7.0, containing $0.5 \mathrm{~mol} \mathrm{~L}{ }^{-1} \mathrm{KCl}$, followed by ultracentrifugation $\left(170,000 \times g, 90 \mathrm{~min}, 4^{\circ} \mathrm{C}\right)$. Finally, the pellet was suspended in $25 \mathrm{mmol} \mathrm{L}{ }^{-1}$ MOPS buffer, $\mathrm{pH}$ 7.0 , to protein concentration of about $20 \mathrm{mg} \mathrm{mL}^{-1}$. The membrane fraction was flash-frozen as granules with liquid nitrogen, and then stored at $-80{ }^{\circ} \mathrm{C}$. The total amount of protein in the membrane fraction was determined by the bicinchoninic acid (BCA) method using the BCA Protein Assay Kit (Bio-Rad, California, USA). Bovine serum albumin (BSA) was used as the standard protein for the assay.

The activity of pMMO in the membrane fraction was measured in a micro-reaction vessel capped with Mininart ${ }^{\circledR}$ valve $(5 \mathrm{~mL}$, Merck KGaA, Darmstadt, Germany) charged with $1 \mathrm{~mL}$ of the reaction mixture of $25 \mathrm{mmol} \mathrm{L}-1$ MOPS buffer, $\mathrm{pH} 7.0$, containing $1 \mathrm{~g}$-protein $\mathrm{L}^{-1}$ of the membrane fraction and $10 \mathrm{mmol} \mathrm{L}^{-1}$ of NADH. Using a gas-tight syringe, $1 \mathrm{~mL}$ of the gas phase in the vessel was withdrawn. Then, the reaction was initiated by introducing $1 \mathrm{~mL}$ of methane gas and performed in a water bath at $25^{\circ} \mathrm{C}$ with stirring.

\section{4. Quantification of pMMO in the Bacterial Cells}

Expression level of $M$. trichosporium OB3b intracellular proteins was determined by sodium dodecyl sulfate-polyacrylamide gel electrophoresis (SDS-PAGE). Samples for the analysis were prepared by extracting proteins from the bacterial cells using, EzBactYeast Crusher (ATTO Corp., Tokyo, Japan). The concentration of the extracted protein was measured using the BCA protein assay kit (Thermo Fisher Scientific K.K., Tokyo, Japan). The protein concentration was adjusted to 2.5 g-protein $\mathrm{L}^{-1}$ by adding a Tris- $\mathrm{HCl}$ buffer $(\mathrm{pH}$ 7.8). Then, $6 \mu \mathrm{L}$ of the cell lysate were transferred into an Eppendorf tube, and $19 \mu \mathrm{L}$ of electrophoresis 
buffer (EzRun, ATTO Corp., Tokyo, Japan) was added for dilution. Then, $25 \mu \mathrm{L}$ of Laemmli Sample Buffer $(2 \times)$ (Bio-Rad, California, USA) was added, suspended, and left at room temperature for $5 \mathrm{~min}$. The electrophoresis sample solution and $5 \mu \mathrm{L}$ of molecular weight markers (All Blue Standards, Bio-Rad, California, USA) were loaded onto $15 \%$ polyacrylamide gel (e-PAGEL, Bio-Rad, California, USA), and electrophoresis was performed at $40 \mathrm{~mA}$ for $75 \mathrm{~min}$. After electrophoresis, the gel was stained with Coomassie brilliant blue (Bio-Safe ${ }^{\mathrm{TM}}$ Coomassie G-250 Stain, BioRad, California, USA).

The gel images were analyzed using ImageJ, to mea-



Methanol production from methane

The reactor was charged with $17.5 \mathrm{~mL}$ of $12.9 \mathrm{mM}$ phosphate buffer, $\mathrm{pH} 7.0$, containing $0.035 \mathrm{~g}$-dry cells $\mathrm{L}^{-1}, 67 \mathrm{nmol} \mathrm{L}^{-1}$ of cyclopropanol, and $14.3 \mathrm{mmol} \mathrm{L}^{-1}$ of sodium formate. The reaction was performed at $25^{\circ} \mathrm{C}$. The curves shown in the graph are drawn as spline curves.

Fig. 2 Methanol Production from Methane in a Batch Reactor Using the Resting Cells of M. trichosporium OB3b Grown in Medium Containing $1.25(\bigcirc), 10(\triangle)$, and $50 \mu \mathrm{mol} \mathrm{L}^{-1}(\square)$ $\mathrm{CuSO}_{4}$ sure the staining intensity of each protein, and the distribution of pMMO in the total intracellular proteins was calculated. The amount of each protein separated by electrophoresis was calculated from the distribution and amount of protein in the electrophoresis sample. The estimation assumed that the band intensity and the protein amount were proportional.

\section{Results and Discussion}

\section{1. Methanol Biosynthesis from Methane Using M. trichosporium OB3b Grown in High Cop- per Concentration Medium}

The activity of $M$. trichosporium OB3b grown in the medium containing high copper concentration for methanol biosynthesis from methane was examined using the resting cells of the bacteria. The reaction conditions reported previously were chosen for the biosynthesis because the amount of methanol obtained in a batch reactor was relatively high $(\sim 152 \mathrm{mmol}$ g-dry cell $\left.^{-1}\right)^{8)}$. Bacterial cells grown in medium containing $50 \mu \mathrm{mol} \mathrm{L} \mathrm{L}^{-1}$ and $10 \mu \mathrm{mol} \mathrm{L}{ }^{-1}$ of copper were used as the biocatalysts prepared at high copper concentration, and the cells grown in medium containing $1.25 \mu \mathrm{mol}$ $\mathrm{L}^{-1}$ copper as the conventional biocatalyst.

The time course of methanol production from methane in a batch reactor is shown in Fig. 2. Bacterial cells grown with $50 \mu \mathrm{mol} \mathrm{L}-1$ of copper produced methanol at a constant rate for about $30 \mathrm{~h}$ after the reaction started, then the rate decreased gradually. Methanol production almost ceased around the reaction time of $60 \mathrm{~h}$, due to the inhibition of pMMO by the produced methanol $^{9)}$. Reaction for $96 \mathrm{~h}$ obtained $234 \mathrm{mmol}$ of methanol per $\mathrm{g}$ of dry-cell, and maximum methanol concentration in the reaction mixture reached about $8 \mathrm{mmol} \mathrm{L}-1$.

Methanol production rate in the initial stage and total amount of methanol were lower using bacterial cells grown with $10 \mu \mathrm{mol} \mathrm{L}-1$ and $1.25 \mu \mathrm{mol} \mathrm{L}{ }^{-1}$ of copper ions (Fig. 2). Table 2 summarizes the methanol productivity (mmol-methanol g-dry cell ${ }^{-1} \mathrm{~h}^{-1}$ ) in the initial stage of the biosynthesis, the total amount of methanol (mmol-methanol g-dry cell ${ }^{-1}$ ), and the maximum meth-

Table 2 Influence of Copper Concentration in the Growth Medium of M. trichosporium OB3b on Methanol Productivity in a Batch Reactor

\begin{tabular}{|c|c|c|c|}
\hline \multirow{2}{*}{$\begin{array}{l}\text { Copper concentration } \\
\text { in the growth medium } \\
\qquad\left[\mu \mathrm{mol} \mathrm{L}{ }^{-1}\right]\end{array}$} & \multirow{2}{*}{$\begin{array}{l}\text { Methanol productivity }{ }^{\mathrm{a})} \\
{\left[\mathrm{mmol} \text { g-dry cell }{ }^{-1} \mathrm{~h}^{-1}\right]}\end{array}$} & \multicolumn{2}{|c|}{ Amount of methanol ${ }^{\text {b) }}$} \\
\hline & & {$\left[\mathrm{mmol}\right.$ g-dry cell $\left.{ }^{-1}\right]$} & {$\left[\mathrm{mmol} \mathrm{L}^{-1}\right]$} \\
\hline 1.25 & $3.07 \pm 0.02$ & $149 \pm 11$ & $5.21 \pm 0.39$ \\
\hline 10 & $5.57 \pm 0.08$ & $167 \pm 10$ & $5.84 \pm 0.35$ \\
\hline 50 & $9.56 \pm 0.04$ & $227 \pm 13$ & $7.95 \pm 0.46$ \\
\hline
\end{tabular}

a) Determined from the reaction period where the production rate of methanol was constant.

b) Amount of methanol produced by 98 -h reaction in $3.5-\mathrm{mL}$ reaction mixture.

c) Results are expressed as means $\pm \mathrm{SD}$ of triplicate experiments $(\mathrm{p}<0.01$ versus each data by $t$-test $)$. 
Table 3 Protein Distribution and Specific Activity of pMMO in the Membrane Fraction from M. trichosporium $\mathrm{OB} 3 \mathrm{~b}$

\begin{tabular}{ccc}
\hline $\begin{array}{c}\text { Copper concentration } \\
\text { in the growth medium } \\
{\left[\mu \mathrm{mol} \mathrm{L} \mathrm{L}^{-1}\right]}\end{array}$ & $\begin{array}{c}\text { Protein distribution of pMMO } \\
\text { in the total intracellular proteins }{ }^{\text {a) }} \\
{[\%]}\end{array}$ & $\begin{array}{c}\text { Specific activity of pMMO } \\
\text { in the membrane fraction } \\
{[\mu \mathrm{mol} \text { g-protein }}\end{array}$ \\
\hline 1.25 & $28 \pm 3$ & $18.2 \pm 0.7$ \\
10 & $42 \pm 4$ & $35.2 \pm 1.2$ \\
50 & $58 \pm 3$ & $48.7 \pm 1.0$ \\
\hline
\end{tabular}

a) Results are expressed as means $\pm \mathrm{SD}$ of triplicate experiments ( $\mathrm{p}<0.01$ versus each data by $t$-test).

anol concentration in the reaction mixture (mmol-methanol $\mathrm{L}^{-1}$ ) obtained in the batch reaction for $96 \mathrm{~h}$. Statistically significant differences were found $(\mathrm{p}<0.01)$ as shown in Table 2 . Compared to the reference biocatalyst (bacteria prepared with $1.25 \mu \mathrm{mol} \mathrm{L}-1$ copper), biocatalysts prepared with $10 \mu \mathrm{mol} \mathrm{L}{ }^{-1}$ and $50 \mu \mathrm{mol}$ $\mathrm{L}^{-1}$ copper showed 1.8- and 3.1-times higher methanol productivity, respectively, and 1.1- and 1.5-times greater total amount of methanol produced in the batch reaction for $96 \mathrm{~h}$. These results indicate that M. trichosporium $\mathrm{OB} 3 \mathrm{~b}$ grown in medium containing high copper concentration achieves improved performance as the biocatalyst for methanol production from methane.

The maximum methanol concentration in the reaction mixture increased with higher copper concentration in the growth medium of the biocatalyst (Table 2), although the concentration is known to be limited due to product inhibition of the biocatalyst ${ }^{9)}$. Previous studies shown in Table $\mathbf{1}$ indicated that the maximum methanol concentration tended to increase with higher cell density in the reaction mixture. In contrast, the methanol synthesis experiments in this study were performed with the same cell density. Therefore, the increase in maximum methanol concentration in our experiment is caused by higher expression of pMMO in the bacterial cells.

\section{2. Quantity and Quality of pMMO in the Bacte- rial Cells}

High expression of pMMO in the bacterial cells of $M$. trichosporium $\mathrm{OB} 3 \mathrm{~b}$ is expected to result in high activity. To confirm this, the membrane fraction was prepared from the bacterial cells, and the pMMO content and activity for methanol production from methane were measured. The pMMO distribution among total proteins in the membrane fraction depended on the copper concentration in the growth medium of the bacteria. The protein distributions showed statistically significant differences $(\mathrm{p}<0.01)$ as shown in Table 3 . The membrane fraction of bacteria prepared with 1.25 $\mu \mathrm{mol} \mathrm{L} \mathrm{L}^{-1}$ copper contained about $28 \%$ of the total proteins as pMMO. The pMMO distribution increased with higher copper concentration, and reached to about $58 \%$ in the bacteria prepared with $50 \mu \mathrm{mol} \mathrm{L}^{-1}$ copper. Therefore, the amount of pMMO in a single bacterial cell increased by about 2.1 times as the copper concen- tration in the growth medium increased from 1.25 to 50 $\mu \mathrm{mol} \mathrm{L}{ }^{-1}$.

Furthermore, the specific activity of pMMO (molmethanol mg-protein ${ }^{-1} \min ^{-1}$ ) dependsed on the copper concentration (Table 3). pMMO activities in the different samples showed significant differences $(\mathrm{p}<0.01)$ as shown in Table 3. The membrane fraction prepared from the bacteria grown with $1.25 \mu \mathrm{mol} \mathrm{L}{ }^{-1}$ copper, had about $18 \mathrm{mmol}$-methanol mg-protein ${ }^{-1} \mathrm{~min}^{-1}$ of pMMO activity, whereas the membrane fraction prepared from the bacteria grown with $50 \mu \mathrm{mol} \mathrm{L}{ }^{-1}$ copper had activity of about $48 \mathrm{mmol}$-methanol $\mathrm{mg}^{- \text {protein }^{-1}}$ $\mathrm{min}^{-1}$ in. Therefore, the pMMO activity increased about 2.7 times as the copper concentration in the growth medium increased from 1.25 to $50 \mu \mathrm{mol} \mathrm{L}{ }^{-1}$. The increase in pMMO activity was higher than the increase in pMMO distribution, indicating that the copper affects not only the quantity of pMMO but also the quality of pMMO in a bacterial cell. The same effect of copper was reported in another methane-oxidizing bacterium, Methylococcus capsulatus (Bath) ${ }^{19)}$. The increase in the quantity and quality of pMMO induced by copper ions contributes to the increase in biocatalytic performance for methanol production from methane.

The increase in methanol productivity of the biocatalyst (3.1-fold) was higher than that in pMMO activity in the membrane fraction (2.7-fold). One of the reasons is that the amount of bacterial membrane also increased with higher copper concentration in the growth medium of the bacteria. Alternatively, the difference is due to the loss of pMMO activity during the preparation of the membrane fraction from the bacterial cells.

\section{3. Repeated Batch Methanol Production from Methane}

Methanol production almost ceased as the amount of methanol produced in the batch reactor increased, which is known to be caused by inhibition of pMMO by the produced methanol9). Therefore, the removal of the product from the reaction mixture would be a useful technique for maintaining methanol productivity during the methane conversion. To confirm this, repeated batch reaction was carried out. A single reaction was carried out for $24 \mathrm{~h}$. After the reaction, the bacterial cells were collected from the reaction mixture using a 
Table 4 Repeated Batch Methanol Production from Methane Using the Resting Cells of M. trichosporium OB3b

\begin{tabular}{cccc}
\hline Reaction & $\begin{array}{c}\text { Amount of cells }{ }^{\mathrm{a})} \\
{\left[10^{-3} \mathrm{~g}_{\text {-dry cell }]}\right.}\end{array}$ & $\begin{array}{c}\text { Methanol concentration } \\
{\left[\mathrm{mmol} \mathrm{L}^{-1}\right]}\end{array}$ & $\begin{array}{c}\text { Methanol productivity } \\
{\left[\mathrm{mmol} \mathrm{g} \text {-dry cell }^{-1} \mathrm{~h}^{-1}\right]}\end{array}$ \\
\hline 1 & 0.122 & $8.07 \pm 0.03$ & $9.61 \pm 0.04$ \\
2 & 0.102 & $7.83 \pm 0.05$ & $9.32 \pm 0.06$ \\
3 & 0.087 & $7.32 \pm 0.03$ & $8.72 \pm 0.04$ \\
4 & 0.070 & $6.73 \pm 0.04$ & $8.01 \pm 0.05$ \\
\hline
\end{tabular}

Single reaction was performed for $24 \mathrm{~h}$ at $25{ }^{\circ} \mathrm{C}$. After the reaction, the bacterial cells were collected from the reaction mixture by using centrifugal filters, and re-used in the next reaction. The reactor contained $17.5 \mathrm{~mL}$ of $12.9 \mathrm{mmol} \mathrm{L}^{-1}$ phosphate buffer, $\mathrm{pH} 7.0$, containing $0.035 \mathrm{~g}$-dry cells $\mathrm{L}^{-1}, 67 \mathrm{nmol} \mathrm{L}^{-1}$ of cyclopropanol, and $14.3 \mathrm{mmol} \mathrm{L}^{-1}$ of sodium formate.

a) The total amount of bacterial cells collected from the reaction mixture except the first reaction.

b) The amount of methanol in the reaction mixture was measured three times.

centrifuge filter, and re-used in the next batch reaction.

Table 4 summarizes the amount of biocatalyst collected from the reaction mixture and the methanol productivity during 4 cycles of the repeated batch reaction. More than $80 \%$ of the biocatalyst was collected by the centrifugation filter from the reaction mixture in each cycle. Furthermore, over $90 \%$ of methanol productivity was retained in the reaction cycle, but was reduced gradually by repeating the cycle. Such decrease in productivity was probably due to disruption of the bacterial cells and the protein structure of pMMO during the methanol synthesis reaction and collection of the biocatalyst ${ }^{9), 18)}$. Over the 4 cycles (total $96 \mathrm{~h}$ ), $\sim 856 \mathrm{mmol} \mathrm{g}$-dry cell $^{-1}$ of methanol was obtained, 3.7fold higher than the amount of methanol in the batch reaction for $96 \mathrm{~h}$. As reported previously ${ }^{9)}$, the total amount of methanol produced from methane was improved by using repeated batch reaction to prevent the product inhibition of pMMO.

\section{Conclusion}

As we expected, $M$. trichosporium OB3b grown in medium containing high copper concentration had improved methanol productivity from methane bioconversion in a batch reactor. The increase in the methanol productivity was due to higher quantity and quality of pMMO in the bacterial cells. The methanol productivity of the biocatalyst prepared in growth medium containing $50 \mu \mathrm{mol} \mathrm{L}{ }^{-1}$ copper was $9.56 \mathrm{mmol}$ g-dryl cell $^{-1} \mathrm{~h}^{-1}$, which was the highest reported productivity in the methane conversion to methanol in batch reactors (Table 1). By optimizing the design of batch reactors and the reaction conditions such as methane to air ratio in the gas phase of the reactor, concentration of formate, and inhibitors for MDH, as suggested in previous studies, the methanol productivity of $M$. trichosporium grown in medium containing $50 \mu \mathrm{mol} \mathrm{L}-1$ copper would approach the required performance of biocatalyst for methane conversion to methanol in industrial use.

\section{Acknowledgment}

This work was partially supported by a Grant-in-Aid for Scientific Research (KAKENHI) (Grant No. 25630363) from the Japan Society for the Promotion of Science (JSPS).

\section{References}

1) Huang, K., Miller, J. B., Huber, G. W., Dumescic, J. A., Maravelias, C. T., Joule, 2, 349 (2018).

2) McFarland, E., Science, 338, 340 (2012).

3) Baba, T., Miyaji, A., "Catalysis and the Mechanism of Methane Conversion to Chemicals $\mathrm{C}-\mathrm{C}$ and $\mathrm{C}-\mathrm{O}$ Bonds Formation Using Heterogeneous, Homogenous, and Biological Catalysts," Springer, Singapore (2020).

4) Meng, X., Cui, X., Rajan, N. P., Yu, L., Deng, D., Bao, X., Chem, 5, 2296 (2019).

5) Zakaria, Z., Kamarudin, S. K., Renew. Sust. Energ. Rev., 65, 250 (2016).

6) Bjorck, C. E., Dobson, P. D., Pandhal, J., AIMS Bioengineering, 5, 1 (2018).

7) Hanson, R. S., Hanson, T. E., Microbiol. Rev., 60, 439 (1996).

8) Takeguchi, M., Furuto, T., Sugimori, D., Okura, I., Appl. Biochem. Biotechnol., 68, 143 (1997).

9) Furuto, T., Takeguchi, M., Okura, I., J. Mol. Catal. A, 144, 257 (1999).

10) Lee, S. G., Goo, J. H., Kim, H. G., Oh, J.-I., Kim, Y. M., Kim, S. W., Biotechnol. Lett., 26, 947 (2004).

11) Kim, H. G., Han, G. H., Kim, S. W., Biotechnol. Bioproc. Eng., 15, 476 (2010).

12) Duan, C., Luo, M., Xing, X., Biores. Technol., 102, 7349 (2011).

13) Pen, N., Soussan, L., Belleville, M.-P., Sanchez, J., Charmette, C., Paolucci-Jeanjean, D., Biores. Technol., 174, 42 (2014).

14) Hwang, I. Y., Hur, D. H., Lee, J. H., Park, C.-H., Chang, I. S., Lee, J. W., Lee, E. Y., J. Microbiol. Biotechnol., 25, 375 (2015).

15) Mehta, P., Mishra, S., Ghose, T., J. Gen. Appl. Microbiol., 33, 221 (1987).

16) Shimoda, M., Okura, I., J. Mol. Catal., 64, L23 (1991).

17) Miyaji, A., Furuya, D., Orita, I., Baba, T., Biores. Technol. Rep., 11, 100473 (2020).

18) Miyaji, A., Methods Enzymol., 495, 211 (2011).

19) Yu, S. S.-F., Chen, S. S.-F., Tseng, M. Y.-H., Wang, Y.-S., Tseng, C.-F., Chen, Y.-J. Huang, D.-S., Chan, S. I., J. Bacteriol., 185, 5915 (2003). 
要旨

高濃度の銅含有培養液で調製したメタン資化細菌 Methylosinus trichosporium OB3b による

メタンからのメタノール合成

宮地 輝光

東京工業大学物質理工学院，226-8502 横浜市緑区長津田町4259-G1-14

メタン資化細菌 Methylosinus trichosporium OB3b による常温 常圧でのメタン転化反応におけるメタノール生産性を高めるた め, $50 \mu \mathrm{mol} \mathrm{L} \mathrm{L}^{-1}$ の銅を含む培地で調製した細菌細胞を生体触媒 として用いた。回分反応器におけるメタン転化反応のメ夕ノー ル生産性は $9.56 \mathrm{mmol}$ g-dry cell ${ }^{-1} \mathrm{~h}^{-1}$ であり, 従来法で用いられ た $1.25 \mu \mathrm{mol} \mathrm{L} \mathrm{L}^{-1}$ 銅を含む培地で調製した生体触媒と比べて約 3 倍に向上した。この生産性向上は, 銅により細菌細胞内の銅含
有メタンモノオキシゲナーゼ発現量と酵素活性の増大に起因す る。ただし, 生体触媒の生成物阻害により反応開始後 60 時間 で反応はほぼ停止した。そこで, 24 時間の反応後に生体触媒 を回収し，次の反応に再利用することで，メタノール合成反応 を4回繰り返し行った。その結果, 得られたメタノール量は約 $856 \mathrm{mmol} \mathrm{g-dry} \mathrm{cell}{ }^{-1}$ に達し，96時間の回分反応と比べて約 3.7 倍に増大した。 